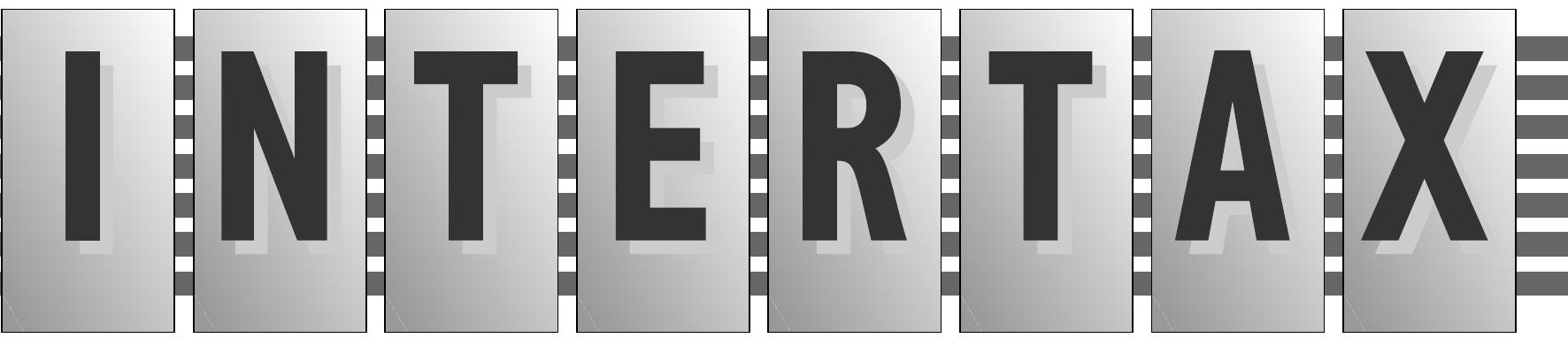

Q. Wolters Kluwer Law \& Business 
Editorial Board:

Fred C. de Hosson, General Editor, Baker \& McKenzie, Amsterdam

Prof. Alexander Rust, University of Luxembourg \& Touche Tohmatsu, Munich

Dr Philip Baker OBE, QC, Barrister, Field Court Tax Chambers, Senior

Visiting Fellow, Institute of Advanced Legal Studies, London University

Prof. Dr Ana Paula Dourado, University of Lisbon, Portugal

Prof. Yariv Brauner, University of Florida, USA

Prof. Edoardo Traversa, Universite Catholique de Louvain, Belgium

Editorial address:

Fred C. de Hosson

Claude Debussylaan 54

1082 MD Amsterdam

The Netherlands

Tel: (int.) +31 205517555

Fax: (int.) +31 205517121

Email: Fred.deHosson@bakermckenzie.com

Book reviews:

Pasquale Pistone

via G. Melisurgo

1580133 Naples

Italy

Email: ppistone@mclink.it

Published by:

Kluwer Law International

PO Box 316

2400 AH Alphen aan den Rijn

The Netherlands

Website: www.kluwerlaw.com

Sold and distributed in North, Central and South America by:

Aspen Publishers, Inc.

7201 McKinney Circle

Frederick, MD 21704

United States of America

Email: customer.service@aspenpublishers.com

\section{Only for Intertax}

Sold and distributed in Germany, Austria and Switzerland by:

Wolters Kluwer Deutschland GmbH

PO Box 2352

56513 Neuwied

Germany

Tel: (int.) +4926318010

Sold and distributed in Belgium and Luxembourg by:

Établissement Émile Bruylant

Rue de la Régence 67

Brussels 1000

Belgium

Tel: (int.) + 3225129845
Sold and distributed in all other countries by:

Turpin Distribution Services Ltd.

Stratton Business Park

Pegasus Drive, Biggleswade

Bedfordshire SG18 8TQ

United Kingdom

Email: kluwerlaw@turpin-distribution.com

Intertax is published in 12 monthly issues

Print subscription prices 2015: EUR 1194/USD 1593/GBP 878

(12 issues, incl. binder)

Online subscription prices 2015: EUR 1106/USD 1474/GBP 813

Intertax is indexed/abstracted in IBZ-CD-ROM; IBZ-Online

For electronic and print prices, or prices for single issues, please contact our sales department for further information. Tel: (int.) +31 (0)70308 1562

Email: sales@kluwerlaw.com

For Marketing Opportunities

Please contact marketing@kluwerlaw.com

Printed on acid-free paper.

ISSN: 0165-2826

(C) 2015 Kluwer law International BV, The Netherlands

All rights reserved. No part of this journal may be reproduced, stored in a retrieval system or transmitted in any form or by any means, electronic, mechanical, photocopying, recording or otherwise, without written permission from the publisher, with the exception of any material supplied specifically for the purpose of being entered and executed on a computer system, for exclusive use by the purchaser of the work.

Permission to use this content must be obtained from the copyright owner. Please apply to: Permissions Department, Wolters Kluwer Legal, 76 Ninth Avenue, 7th Floor, New York, NY 11011-5201, USA. Email: permissions@kluwerlaw.com.

Printed and Bound by CPI Group (UK) Ltd, Croydon, CRO 4YY.

Articles can be submitted for peer review. In this procedure, articles are evaluated on their academic merit by two (anonymous) highly esteemed tax law experts from the academic world. Only articles of outstanding academic quality will be published in the peer-reviewed section. 


\title{
Expatriate Taxation in Spain: Some Reflections for Debate
}

\author{
Aurora Ribes Ribes*
}

The aim of this article is to discuss the Spanish tax regime for expatriates, currently envisaged in Article 93 of the Individuals' Income Tax Act. The purpose of this favourable system was to strengthen Spain's international competitiveness by attracting recipients of high income and foreign investment. However, the option to be taxed as a non-resident (exclusively on the Spanish sourced income and at 24\%) for the five subsequent years, provided certain conditions are met, gives rise to some controversial questions both in the light of the constitutional principles and in the international field.

The article provides insight into the expatriate tax treatment of other European Union (EU) Member States, by examining the different approaches to the same topic. This comparative experience is taken into account for our criticism and proposals for an alternative design of a new Spanish expatriate taxation system.

\section{THE SPANISH TAX REgIME FOR EXPATRIATES: MAIN FEATURES}

\section{I.I Content and Purpose}

The international mobility of highly skilled workers, and in particular of human resources in science and technology, is currently an important policy issue in most OECD countries. ${ }^{1}$ The Spanish tax regime for expatriates was established by virtue of Act 62/2003, of 30 December 2003, concerning social, administrative and fiscal measures, ${ }^{2}$ by introducing a new paragraph 5 in section 9 of the Personal Income Tax Act 40/1998, which became applicable on 1 January 2004.

After several changes, the regime is currently regulated in Article 93 of the Personal Income Tax Act 35/2006. The 'special tax regime for foreign employees expatriated to Spain' grants natural persons who acquire their tax residence in Spain as a result of their transfer to this country the possibility to opt between paying tax under the personal income tax rules or under the non-residents' income tax rules, without renouncing their status as personal income taxpayers. In the latter case, personal income tax liability is determined according to the rules set out in the Non-Residents' Income Tax Act, which establishes the application of a $24 \%$ fixed tax rate, instead of the progressive rate envisaged in the Personal Income Tax Act, for the subsequent five years.

The declared purpose of this measure was to attract foreign experts to Spanish institutions and enterprises in order to strengthen Spain's international competitiveness. Evidently, the justification of the regime is founded on the consideration that we are faced with a 'third category of taxpayer', the temporary resident, who differs from residents and non-residents stricto sensu, and consequently deserves a different tax treatment that takes their temporary stay in Spain for labour reasons into account.

\section{I.2 Requisites: Some Critical Remarks}

This preferential tax treatment for expatriates applies provided that certain conditions are met:

(1) The expatriates must not have been residents in Spain in the ten years prior to their transfer to Spanish territory.

This requisite is excessive for several reasons. To begin with, neither the nationality of the employee nor the actual place of residence is relevant. Consequently, in the case of Spanish nationals

\section{Notes}

Tax Law Professor. University of Alicante (Spain). The author can be contacted at aurora.ribes@ua.es.

See: 'International Mobility of the highly skilled', OECD, 2002 [http://www.google.se/books?hl=sv\&lr=\&id=lcuxq29bXloC\&oi=fnd\&pg=PA71\&dq=OECD++intern ational + mobility + of + the +highly + skilled\&ots=HNrfpLI0Cy\&sig =TAsmCHTWf2uXW5JyJ34Z73mSxUA\&redir_esc=y\#v=onepage\&q=OECD $\% 20 \% 20$ international $\% 20$ mobility $\% 20$ of $\% 20$ the\%20highly\%20skilled\&f=false], accessed 22 Dec. 2014

Official Spanish Gazette of 31 Dec. 2003. 
transferred abroad, the preferential treatment will not be applied if they return to Spain before this period of ten years. ${ }^{3}$

Likewise, the clause does not distinguish between residents in European Member States or in a third country. According to the fundamental freedoms envisaged in the Treaty on the Functioning of the European Union (hereinafter, TFEU), and particularly bearing in mind the principle of the free movement of workers, this distinction should be introduced into the Spanish regulation.

Furthermore, as some authors have pointed out, ${ }^{4}$ the period of ten years seems to be too long. On this point, it is important not to lose sight of the increasing mobility of labour on the international level, which will clearly be hindered by this restriction. Therefore, from a lege ferenda point of view, the limitation of this period to five years should be considered.

(2) Their transfer to Spain must be the consequence of an employment contract. It is considered that this requisite is fulfilled when an ordinary, special or statutory employment relationship is initiated with an employer in Spain, or when the transfer is ordered by the employer, who issues an employee transfer letter, and the taxpayer does not obtain income through a permanent establishment in Spain.

Needless to say, as an employment contract stricto sensu is required, the option cannot be exercised by a sportsperson (a golfer or tennis player, for instance) with a professional income.

(3) The work must be effectively performed in Spain. This condition is considered fulfilled even when part of the work is performed abroad, provided that the salary received for such work - regardless of whether it is considered income obtained in Spanish territory - does not exceed $15 \%$ of the total salary received for work performed in each calendar year. When, pursuant to the provisions of the employment contract, the taxpayer renders his/her services abroad in another company belonging to the same group, the limit is $30 \%$. If the specific amount of earnings corresponding to work performed abroad cannot be accredited, it will be calculated according to the number of days the worker effectively spends abroad.
Of relevance in this regard is the Resolution of the Spanish General Tax Directorate of 16 May 2007. The case in question concerned an airline entity resident in Spain, which employed flight crew who, as a consequence of this employment, became resident in Spain. Due to the fact that this crew generally cruised in international airspace, the Spanish General Tax Directorate determined that the total work performed could be considered related to the entity resident in Spain and, thus, income obtained in Spanish territory. Hence, in this case, it was not required that the salary received for such work should not exceed $15 \%$ of the total salary received for work performed in each calendar year.

(4) The work must be performed for a company or entity resident in Spain or for the permanent establishment in Spain of a non-resident entity. It is considered that this condition is met when the work benefits a company or entity resident in Spain or the permanent establishment in Spain of a non-resident entity. If the transfer takes place within a group of entities, the worker must be hired by the company resident in Spain, or the transfer to Spain must be ordered by the employer.

(5) The earned income derived from this employment relationship must not be exempt from Non-Residents' Income Tax.

This requisite raises the question of whether the option should be applied in the hypothesis of partial exemption. In our opinion, there is room for equity as long as the majority of the income is levied; this favourable regime could thus be applied in this situation, in the light of the principle of proportionality. $^{5}$

(6) The foreseeable salaries arising from the employment contract with regard to each of the fiscal years applying this special regime must not exceed EUR 600,000 . However, this condition will not be applied to those taxpayers expatriated to Spanish territory prior to 1 January 2010.

Due to opposition from experts, the ruling was changed as of 1 January 2010, by introducing this limitation. The first question on this issue concerns the Spanish Constitution itself, to the extent that this measure was

In this case we are faced with a discrimination á rebours (it has adverse effects on Spanish nationals in comparison to nationals of other Member States), which is not prohibited by the Treaty on the Functioning of the European Union. See, in this respect: Herrera Molina, P.M.: 'La discriminación inversa en el Derecho Comunitario', in Impuestos No. 1, 1997, pp. 1144 et seq.

Chico de la Cámara, P.: 'Los regímenes tributarios especiales que concede nuestro sistema tributario a los deportistas para favorecer la generación de renta en nuestro país', in Revista jurídica del deporte y entretenimiento No. 17, 2006, p. 164; Gorospe Oviedo, J. I.: 'Los regímenes opcionales de "impatriados" y de no residentes en la imposición sobre la renta', in Quincena Fiscal No. 7, 2010, p. 22.

5 Gorospe Oviedo, J. I.: 'Los regímenes (...)'. Supra p.23. 
established by the Finance Act 26/2009, of 23 December $2009,{ }^{6}$ which does not constitute a valid vehicle to create ex novo a limit, but only to amend the tax rate, deductions on tax liability and other quantitative aspects envisaged in the Income Tax Act 35/2006. Thus, the requisite of a 'substantive tax Act' established by section 134.7 of the Spanish Constitution is not fulfilled. ${ }^{7}$

Moreover, the wording of the ruling raises the question of the interpretation of 'foreseeable salaries'. ${ }^{8}$ Different meanings can be adopted in this respect (we can interpret it as the salaries earned during the previous year, or those expected to be earned), with the subsequent lack of legal certainty for both the taxpayer and the Tax Administration. First, because no definition of this concept is given, and, secondly, because due to the nature of the employments performed, the earnings of this group of transferred workers usually vary substantially from one year to another, which implies an additional problem as regards establishing a reference in this context.

A further issue we would like to highlight is the minimum effect of this measure in terms of tax collection. It has been calculated that approximately 2,000 individuals benefit each year from this option, but only $10 \%$ of them are recipients of an income up to EUR 600,000 . In fact, this may even entail negative consequences in the case of transfers of top executives to other countries, as it will probably imply the change of residence of human capital that will not be taxed in Spain, quite apart from the lost opportunity to generate knowledge and technology. From this perspective, the Spanish expatriate regime is no longer competitive ${ }^{9}$ in comparison to other European systems, as we will discuss next.

In addition to the critical comments noted above, from our point of view this regime should have been addressed to those employees with specialist knowledge or skills in a specific area which are in short supply in the Spanish labour market. In other words, the employee should meet both requirements to qualify. Although in theory the legislator's purpose was to incentivize the establishment in Spain of multinational entities, either parents or subsidiaries, together with scientists, top managers, international researchers and highly qualified professionals and experts, in practice the scope of application of this regime largely exceeds ${ }^{10}$ these groups of transferred workers whose skills, specialized education or knowledge are in demand in Spain.

Of special interest in this respect is the granted regulation of Vizcaya ${ }^{11}$ (Basque Country, Spain), which establishes this optional treatment only for those foreign experts engaged in highly qualified employments directly and mainly related to the activity of research and development. In our view, given the controversial questions derived from this regime from a constitutional perspective, this is the only reason that could be accepted as a justification ${ }^{12}$ for maintaining this system, which contravenes to the principle of equality, based on the desirability of attracting specific strategic activities that need to be promoted in Spanish territory.

\section{I.3 Other Controversial Issues}

\section{I.3.I Compliance with the Tax Justice Principles Envisaged in the Spanish Constitution}

Additionally, the Spanish tax regime for expatriates merits reflection as regards the constitutional principles of equality and ability to pay (section 31.1 of the Spanish Constitution). In the case of the latter, Spanish constitutional case law has sometimes recognized the prevalence of an extra-fiscal objective over a contributive justification. ${ }^{13}$ However, it should be noted that we are faced with a regressive tax benefit ${ }^{14}$ - now eradicated in most European jurisdictions - which favours high income recipients by reducing tax liability when the tax base grows.

Concerning the principle of equality, in its judgment 96/2002 of 25 April 2002, the Spanish Constitutional Court declared the compatibility of exemption measures (or measures of economic policy, as in the present case) with this principle, provided they are proportional and intended to achieve a legitimate purpose. Thus, the underlying question is whether proportionality exists between the means used (reduced flat rate taxation) and the objective pursued (to foster the entry of highly qualified workers into Spain).

\section{Notes}

The Finance Act 26/2009, of 23 December introduced, through its Final Disposition 13.1, a new para. f) in the pre-existing s. 93 of Act $35 / 2006$

García Carretero, B.: 'La fiscalidad de los trabajadores desplazados en un entorno de globalización y deslocalización', Monografías AEDAF, no. 1, 2006, p. 138; Falcón y Tella, R.: 'Modificaciones en el régimen de los nuevos residentes: España (ley Beckham), Portugal y el Reino Unido', in Quincena Fiscal No. 21 , 2009 , p. 7.

Díaz-Súnico, G.: 'Una vuelta de tuerca a la “Ley Beckham”, in Quincena Fiscal No. 4, 2010, pp. 93-97.

Falcón y Tella, R.: 'Modificaciones (...)'. Supra p. 10.

Carmona Fernández, N.: ‘Guía del Impuesto sobre la Renta de No Residentes’, second edition, CISS, Valencia, 2007, p. 253.

Article 4, para. 3, a) of Foral Act 13/2013, of 5 December, on the Income Tax Act.

Gorospe Oviedo, J. I.: 'Los regímenes (...)'. Supra p. 39

See, for instance, the following Spanish Constitutional Court decisions: 27/1981, of 20 July; 37/1987, of 26 March; 150/1990, of 4 October; 221/1992, of 11 December and 134/1996, 22 July. In this case, the extra-fiscal objective would be founded on Art. 130.1 of the Spanish Constitution.

14 García Carretero, B.: 'La fiscalidad (...)'. Supra p.157. 
In our opinion, although it is obvious that this initiative strengthens the competitiveness of our economy in a globalized world; ${ }^{15}$ it is also true that the regime is unacceptable from the point of view of the equality principle, ${ }^{16}$ and provokes dysfunctions in the coherence of the personal tax itself, as it constitutes an exception to the general rule of taxation of residents in Spain under the personal obligation system (unlimited tax liability).

Furthermore, as is well known, the general character of this clause has immediately led to its application to the field of sport. The measure was initially ${ }^{17}$ welcomed by football clubs, which usually pay the football players' taxes. In this context, the justification lies in the desirability of promoting the most competitive and profitable football market in Spain, in comparison to professional leagues in other countries. ${ }^{18}$ The great social and economic importance that professional sport has now acquired explains why this activity has spread beyond the field of sport to become a business. We are unquestionably faced with an important market in the State's economy, and one which moves large sums of money (especially through screening rights, merchandising, rights of image, and currency from the tourists). However, it should be noted that in this case, the extra-fiscal objective turns into a fiscal one. Consequently, when we are talking about professional players, the question is whether this fiscal reason (tax collection) is strong enough to take precedence over the ability to pay principle. ${ }^{19}$ The answer, in my view, should be negative, given the Spanish constitutional case law mentioned above.

However, we also have to keep in mind the negative effects caused by this regime in the sphere of sport, as most Spanish football clubs have opted to sign up football players from abroad instead of those resident in Spain, in order to optimize the application of this system. ${ }^{20}$
In conclusion, from the perspective of the equality principle, we consider that the option implies a legitimate measure which is, however, disproportionate ${ }^{21}$ from both the qualitative (beneficiaries) and quantitative point of view. Meanwhile, from the perspective of the ability to pay principle, only an extra-fiscal purpose could take priority, so it may be deduced that in this context, the tax recovery efficiency principle should not prevail over constitutional principles.

\subsubsection{Practical Problems in the Field of Double Tax Treaties}

As we have pointed out, if a taxpayer opts for application of this special regime, personal income tax liability is determined in accordance with the rules set out in the Non-Residents' Income Tax Act (except the provisions contained in sections 5, 6, 8, 9, 10 and 11). However, it will be applicable only to the Spanish-source income that is not obtained through a permanent establishment.

Pursuant to the terms of the second paragraph of section 120 of the Personal Income Tax ruling, if reciprocity exists, the Minister of Finance may indicate the cases in which certificates shall be issued attesting to tax residence in Spain for taxpayers who have opted for application of this special regime, for the purposes of the provisions of double taxation conventions signed by Spain. The certificate of tax residence in Spain ${ }^{22}$ is a document issued by the Spanish Tax Administration to individual income taxpayers who must accredit their tax residence in Spain before the tax authorities of other countries, or for double tax treaty purposes. ${ }^{23}$

Nevertheless, this latter possibility is only apparent, since the majority of the double tax treaties subscribed by

\section{Notes}

15 Relea Sarabia, A.: 'El régimen jurídico-tributario de la retribuciones de los futbolistas', Thomson-Aranzadi, 2007, p. 89; De Pablo Varona, C.: 'El régimen fiscal para deportistas desplazados ("impatriados") y la aplicabilidad de las exenciones establecidas en el Impuesto sobre Renta de los No Residentes', in Revista jurídica del deporte y entretenimiento No. 23, 2008, p. 238.

16 Besides, Martínez-Carrasco Pignatelli stated that it would also be desirable to introduce a requisite concerning reciprocity in the outbound State, so that the Spanish national who moves there for labour reasons could benefit from a similarly advantageous tax treatment. Martínez-Carrasco Pignatelli, J. M.: 'El régimen fiscal especial para trabajadores desplazados en la Ley 35/2006 del IRPF', in Quincena Fiscal No. 12, 2007, p. 22.

17 In practice, however, this privileged regime would not be so advantageous for some taxpayers, due to the fact that it excludes the application of reductions and other fiscal benefits. For this reason, it is advisable to analyse on a case-by-case basis. See, on this question: Ortiz Calle, E.: 'El régimen fiscal de los "impatriados" en el Impuesto sobre la Renta de las Personas Físicas: el supuesto particular de los deportistas profesionales', in Revista jurídica del deporte y entretenimiento no. 23, 2008, p. 20; Pérez Bernabeu, B.: 'The new tax regime for expatriates in Spain', in Intertax vol. 34, No. 5, 2006, pp. 267-271.

18 Landa Aguirre, L.: 'Los derechos de explotación de la imagen, los deportistas y la opción de tributación en el Impuesto sobre la renta de los no residentes', in Jurisprudencia tributaria Vol. III, 2004, p. 65.

9 Ortiz Calle, E.: 'El régimen fiscal (...)'. Supra p. 27.

20 Chico de la Cámara, P.: 'Algunas propuestas de lege ferenda del régimen tributario especial para favorecer el desplazamiento de deportistas a nuestro país (Régimen de “impatriados”)', in: Chico de la Cámara, P. (Dir.): 'Régimen tributario del deporte', Civitas - Thomson Reuters, 2013, p. 100. For anexample of the taxation of a Managing Director of a Spanish football club that opts for this regime, see: De las Heras, V.: 'Nuevo régimen fiscal de los impatriados', in Revista jurídica de deporte y entretenimiento No. 17, 2006, pp. 477 and 478 .

21 The restructuring of tax systems in recent decades seems questionable in terms of tax equality, due to the fact that social justice has been eclipsed by economic growth, and the latter depends to a great extent on international competitiveness. Steinmo, S.: 'Taxation and democracy', New Haven: Yale University Press, 1993.

22 These two types of certificate of residence are regulated in the Annexes IV and V of the Ministerial Order 3316/2010, of 17 December. The taxpayer may file the request electronically or in hard copy. The Administration will carry out the appropriate verification and, in a maximum of ten working days after filing of the request, will issue a certificate in the same format as the request was made, or, where appropriate, will issue a notification that the request has been refused.

23 Martín-Abril y Calvo, D.: 'El nuevo régimen de tributación por el Impuesto sobre la Renta de No Residentes o régimen de "Impatriados"', in Carta Tributaria No. 16, 2005 , pp. 20 and 21. 
Spain follow the wording of Article 4.1 OECD MC. As is well known, Article 4, paragraph 1 OECD MC states that:

For the purposes of this Convention, the term 'resident of a Contracting State' means any person who, under the laws of that State, is liable to tax therein by reason of his/her domicile, residence, place of management or any other criterion of a similar nature, and also includes that State and any political subdivision or local authority thereof. This term, however, does not include any person who is liable to tax in that State in respect only of income from sources in that State or capital situated therein.

In other words, although the expatriate is considered a taxpayer under the Spanish Income Tax Act, he/she will only be able to obtain the certificate of residence in Spain for domestic purposes (the one established in the Annex IV of the Ministerial Order 3316/2010), but not the certificate of residence in Spain for tax treaty purposes (Annex V of the mentioned Order).

Consequently, although the certificate of residence in Spain would a priori involve the application of the tax treaty, in practice the Spanish Tax Administration could not issue this certificate with regard to double tax treaties that follow the OECD MC. ${ }^{24}$ As a result of that clause, the expatriates that exercise the option to be levied only on their sourced income will automatically lose the protection of the double tax treaty, in case it provides this exclusion clause.

This situation derives from the fact that the concept of tax residence provided in domestic law and in tax treaties does not always coincide. As we have pointed out, most of the double taxation conventions signed by Spain ${ }^{25}$ follow the wording of the OECD MC on this point. In cases in which the treaty contains the provision envisaged in the second sentence of this article, the individual cannot take advantage of the double tax treaty in question since for purposes of this treaty he/she is not a resident in any of the Contracting States. Under this hypothesis, the result is that the expatriate is liable to tax as a non-resident in both States, and only pays tax under the limited tax liability. In other words, he/she does not pay tax on his/her worldwide income in either State, so the progressive effect of the taxes in both States is avoided, with the resulting tax savings. If we refer to the Commentary on Article 4.1 OECD MC, we will see that no provision is made to mitigate this situation.

In our view, a possible solution would be the inclusion of a specific clause (matching clause) in the Spanish double tax treaties in order to cover the particular situation of expatriate taxpayers.

\section{TAX TREATMENT FOR EXPATRIATES FROM A COMPARATIVE LAW PERSPECTIVE}

\section{I The British Remittance Basis System}

The British regime for expatriates has been used as a model to design the Spanish one. ${ }^{26}$ United Kingdom (UK) tax law distinguishes three different types of taxpayers who are considered UK residents: (a) Ordinarily resident: taxpayers who usually live in the UK and have their domicile there; (b) Not ordinarily resident: taxpayers considered UK residents for tax purposes, although they usually live abroad; and, (c) Resident but not domiciled:27 taxpayers who are considered to be UK residents, but are regarded as domiciled ${ }^{28}$ in another country. This status allows the taxpayer to choose between worldwide taxation applicable to UK resident/domiciled taxpayers and 'remittance basis' taxation.

Under the remittance basis system, resident but not domiciled taxpayers are taxed only on their earnings from UK sources if their foreign income and gains are not brought into the UK. That is to say, they will be levied on these latter gains and income only in the case that they are transferred (remittance basis) to the UK.

However, the amendments introduced in 2008 and 2012 have restricted the application of this favourable regime. The Finance Bill of 2008, which amended the Income Tax Act of 2007, established that, as of the tax year starting on 6 April 2008, non-domiciled individuals who are UK residents for tax purposes in the current year and choose the remittance basis of taxation must pay an annual charge of GBP 30,000 ('remittance basis charge') on unremitted foreign income and capital gains if they

\section{Notes}

24 In accordance with Art. 4.1, second sentence of the OECD MC, only full liability to tax (worldwide taxation) determines tax residence in a territory. See, in this regard: López Lubián, J.I.: 'El régimen fiscal de los impatriados. Problemas de aplicación y alternativas de reforma', in Cuadernos de formación, volumen 1/2006, colaboración 04/ 06, Instituto de Estudios Fiscales, 2006, p. 58; Pérez Bernabeu, B.: 'The new (...)'. Supra pp. 269-271; Álvarez Barbeito, P. and Calderón Carrero, J.M.: 'Reflexiones sobre el régimen especial de los impatriados en el IRPF', in Revista de contabilidad y tributación No. 309, 2008, p. 41; Chico de la Cámara, P.: 'Algunas (...)'. Supra pp. 96 y 97; Sala Galvañ, G.: 'Análisis del régimen especial de impatriados aplicado a los deportistas profesionales (Art. 93 LIRPF)', in Tribuna Fiscal No. 273 , 2014 , pp. 29 and 37-39.

25 Spain currently has seventy-seven double tax treaties in force, sixteen of which envisage this exclusion clause (Algeria, Austria, Brazil, Bulgaria, Canada, China, Ecuador, Finland, Indonesia, Japan, Malaysia, Morocco, the Netherlands, Switzerland and Singapore).

López Lubián, J.I.: 'El régimen (...)'. Supra p. 55

27 With regard to the differences in treatment between the not ordinarily resident and the resident but not domiciled, see: 'Residence, domicile and the remittance basis', guidance provided by Her Majesty's Revenue \& Customs (HMRC), at http://www.hmrc.gov.uk/cnr/hmrc6.pdf (accessed 15 Dec. 2014).

28 As understood in UK tax law, 'domicile' indicates, generally speaking, the country where an individual belongs by virtue of his origin ('domicile of origin'), whereas 'residence' refers to the country where the individual lives. Cerioni, L.: 'New rules for resident/non-domiciled taxpayers in the United Kingdom', in Bulletin for International Taxation vol. 62, No. 12, 2008, p. 551 
were resident for more than seven ${ }^{29}$ of the immediately preceding nine tax years. ${ }^{30}$

In other words, this system imposes the payment of an annual charge ${ }^{31}$ for the privilege of using the remittance basis. If they do not pay this 'remittance basis charge', they will be taxed in the UK on their foreign income when it arises, regardless of whether or not it is remitted to the UK.

In addition, irrespective of the length of their UK residence, non-domiciled taxpayers who claim the remittance basis of taxation also lose their personal income tax allowances and the annual exempt amount under the capital gains tax. ${ }^{32}$ These new rules do not apply if the unremitted foreign income and gains amount to less than GBP 2,000.

Whether or not to claim the remittance basis is an annual choice, which provides a regular tax planning opportunity. As Lagerberg ${ }^{33}$ pointed out, some taxpayers may not want to use the remittance basis each year, for instance, if they have fluctuating or changing sources of income. Furthermore, if a husband and wife both fall within the 'remittance basis charge', they may be able to move income and gains (legitimately and tax efficiently) between each other so that only one charge is required. Consequently, the decision as to whether it is worth paying the remittance basis charge will depend on reviewing the taxpayer's entire tax exposure both in the UK and abroad.
As of the tax year 2012-2013, the remittance basis system has been modified again by increasing the amount of the remittance basis charge to GBP 50,000 for those taxpayers who have been resident in the UK for at least twelve of the previous fourteen years. ${ }^{34}$ Therefore, although no limitation exists with regard to the number of years a taxpayer can benefit from this system, it is also true that these recently introduced changes ${ }^{35}$ may discourage the resident but not domiciled from benefiting sine die of this special regime. ${ }^{36}$

However, application of the remittance basis system has turned out to be extremely complex and controversial, for several reasons: firstly, the concept of remittance is not clear, ${ }^{37}$ and has been discussed in many British Courts' decisions; secondly, this regime gives rise to problems concerning European Union (EU) law as a result, for instance, of leaving foreign tax bases aside ${ }^{38}$; and, thirdly, the system could be inconsistent with the double tax treaties $^{39}$ in force.

\subsection{The Portuguese Regime for Non-habitual Residents}

Like many other European countries, Portugal has recently designed an advantageous tax regime for workers transferred to its territory. The aim of the regime for nonhabitual residents, introduced by Decree Law 249/2009, of 23 September $2009^{40}$ and complemented by Ordinance

\section{Notes}

29 It should be noted that this remittance basis charge does not affect top managers temporarily in the United Kingdom, who return to their State of origin prior to this period (seven years); thus, the British system continues to be competitive in comparison to other countries. Falcón y Tella, R.: 'Modificaciones (...)'. Supra p. 9.

See: Sch. 7 of the Finance Act 2008, available at: http://www.legislation.gov.uk/ukpga/2008/9/pdfs/ukpga_20080009_en.pdf (accessed 15 Dec. 2014). The GBP 30,000 tax charge is effectively an advance payment of tax for 'nominated foreign income and gains' that are not remitted in the tax year.

This means a loss of over GBP 2,400 in relation to income tax and over GBP 1,600 for capital gains. Lagerberg, F: 'Residence and domicile (remittance basis)', in British Tax Review No. 5, 2008, p. 426

Lagerberg, F: 'Residence (...)'. Supra p. 426.

See: 'Guidance Note: Changes to the remittance basis', published 28 May 2012, at: http://www.hmrc.gov.uk/cnr/guide-remit.pdf (accessed 15 Dec. 2014).

5 Especially those concerning the remittance basis, but also the loss of personal tax allowances. As noted above, only a taxpayer whose unremitted foreign income and gains amount to less than GBP 2,000 continues to benefit from the remittance basis treatment by default, keeps the personal tax allowances, and is not required to pay the remittance basis charge.

Sanz Clavijo, A.: 'Propuestas para la reforma del régimen de impatriados español desde una visión de Derecho Comparado’, in Crónica Tributaria No. 148, 2013 , p. 199.

Álvarez Barbeito, P. and Calderón Carrero, J.M.: 'Reflexiones (...)'. Supra p.43.

Whiteman, P.G.: 'Income tax', 4th ed., Sweet and Maxwell, London, 2012

The British regime specifies that the remittance basis charge constitutes an income tax or capital gains tax at the choice of the taxpayer concerned and should be treated as such for purposes of double taxation treaties. This gives rise to the following question: is the other contracting State obliged to allow the remittance basis charge as a credit against its tax under its tax treaty with the UK which is based on the OECD MC? The UK tax administration has addressed this issue by stating that it is up to each country to decide whether the GBP 30,000 (now 50,000) charge falls under the terms of its treaty with the UK. Cerioni, L.: 'New rules (...)'. Supra p. 552.

Hence, the fundamental point remains that the UK, when it is not the State of residence under the treaty's tie-breaker rules, taxes the income or gains accruing to the taxpayer in his/her own State or that the UK, when it is the residence State, expects the source State to give a tax credit for the remittance basis charge, which can be regarded by the other State as inconsistent with the provisions of the treaty.

In this respect, the OECD Committee on Fiscal Affairs suggested in the Commentaries to the 2005 OECD MC that where a remittance basis system, such as the British or the Irish systems, is applied, a specific clause should be introduced in order to guarantee that the treaty is only applied when the income is taxed in the taxpayer's State of residence. To sum up, it should be assumed that individuals applying the remittance basis system do not benefit from double tax treaties, except when they may be affected by a double taxation situation.

The proposal of the OECD Committee on Fiscal Affairs is based on British tax treaty practice (see, for example, the double tax treaties between the UK and Sweden, or between the UK and Denmark), which has been incorporating similar clauses in order to limit or temporarily defer application of the source State's provisions regarding income obtained by non-domiciled residents until the date of the remittance. Schwarz, J.: 'Tax treaties: UK law and practice', Sweet and Maxwell, London, 2002, pp. 146 and seq.

40 In particular, s. 4 of the aforesaid Decree Law 249/2009 amended some articles of the Código do Imposto sobre o Rendimento das Pessoas Singulares (CIRS). The Decree Law is available at http://dre.pt/pdf1s/2009/09/18500/0677406783.pdf (accessed 16 Dec. 2014). 
$12 / 2010$, of 7 January $2010,{ }^{41}$ is to attract highly qualified and high net worth foreign individuals and foreign pensioners into Portugal.

In the past few years however, several concerns have arisen about the effectiveness of this regime. In order to 'unlock' the regime, Article 5 of Act 20/2012, of 14 May 2012, that approved the State Budget for 2013, clarified the requirements envisaged for its application.

In broad terms, this regime is applicable to individuals who meet the criteria to qualify as tax residents in Portugal under the Portuguese tax residency rules ${ }^{42}$ (namely, living in Portugal for more than 183 days during the relevant year, or the possession of a dwelling, on the 31 December of the relevant year, that they intend to use as their habitual residence), and who have not been taxed as tax residents in Portugal in the previous five years.

In contrast to the Spanish regime for expatriates, the Portuguese system focuses on citizens that perform labour, professional or business activities of high added value of a scientific, artistic or technical nature. The table of activities $^{43}$ considered of high added value for these purposes are cited by the previously mentioned Ordinance $12 / 2010$.

Apart from the beneficiaries, there are two other notable differences in comparison to the Spanish system. The first one concerns the right of a non-habitual resident to be taxed in accordance with the non-habitual resident tax scheme for a period of ten consecutive years, from the year of registration as a resident on Portuguese territory, provided that he/she continues to be deemed resident in each of the ten years (section 16.9 CIRS). The second refers to waiver and exclusion, because although the period of ten years is not extendable, whenever the citizen has not benefited from this special regime in one or more years of that ten-year period, he/she may still benefit again from it in any of the remaining years of that period, provided the citizen still has resident status for income tax purposes (section 16.10 CIRS).

Regarding the content of the regime, once granted, non-habitual residents may benefit from several tax advantages for a period of ten years. To begin with, this type of taxpayer may be subject to a special personal income tax rate of $20 \%$ - section 72.6 CIRS - instead of the maximum effective tax rate amounting to $56.5 \%$. Furthermore, provided certain conditions are met, nonhabitual residents are exempt from tax on labour income (dependent and independent), interest, capital gains, rents and pensions obtained outside Portugal, so long as they are or may be taxed in the corresponding source States, pursuant to the double tax treaties signed by Portugal. Given these important advantages, it is not surprising that the number of foreign people applying for the nonhabitual residents' regime has been growing in recent years.

\subsection{The Expatriate Tax Regime in Belgium}

Special rules have been issued by the Belgian tax authorities concerning the tax treatment of foreign executives, researchers and specialists working temporarily in Belgium. ${ }^{44}$ This regime applies to non-Belgian executives who exclusively perform activities which require a special knowledge and responsibility, and thus carry out executive functions, and who work in Belgium because: (a) they have been seconded to Belgium by a foreign enterprise to work temporarily in one or several branches of the said enterprise, or in one or several companies controlled by the enterprise; or, (b) they have been seconded to Belgium by a foreign enterprise which is part of an international group, to work temporarily in one or more Belgian companies which are part of the said group, or in a controlling and coordinating office set up within the international group; or, (c) they have been directly recruited abroad by a Belgian company affiliated with a foreign company, or by a Belgian enterprise that is part of an international group, to work temporarily for the Belgian company or enterprise itself or in a controlling and coordinating office established in Belgium by the international group.

Provided that their activities in Belgium are temporary, the special tax system also applies to: foreign company directors, foreign specialized personnel of the abovementioned branches or companies, and foreign researchers sent from their parent institutions or directly recruited abroad to perform their activities in laboratories and scientific research institutions. As mentioned above, the individual must not be a Belgium citizen and should demonstrate that he/she has maintained personal and economic ties abroad.

The significant benefits offered by this regime can be summarized as follows:

\section{Notes}

41 A version of the Código do Imposto sobre o Rendimento das Pessoas Singulares (CIRS) is available at the website of the Portuguese Tax and Customs Authority (Portal das Finanças): http://info.portaldasfinancas.gov.pt/pt/informacao_fiscal/codigos_tributarios/irs/(accessed 16 Dec. 2014).

42 The non-habitual resident tax regime is available for citizens meeting the following conditions: a) deemed resident on Portuguese territory for tax purposes, according to any of the criteria defined under Art. 16, para. 1 or 2 of the Portuguese Personal Income Tax Code (CIRS), in the year to be taxed as a non-habitual resident; and, b) has not been deemed resident on Portuguese territory during the five years prior to the year to be taxed as a non-habitual resident. With regard to administrative questions, see: info.portaldasfinancas.gov.pt/NR/rdonlyres/B351614F-10BD-4C08-BE44-26CAB723884A/0/IRS_RNH_EN.pdf (accessed 16 Dec. 2014).

43 Available at http://dre.pt/pdf1s/2010/01/00400/0004000040.pdf (accessed 16 Dec. 2014). See: Almeida Fernandes, J. and Pereira, A.: 'Government lists professions eligible for non-habitual resident tax regime', in Tax Notes International vol. 57, No. 3, 2010, p. 239.

44 Anthony, R.: 'Fiscal residence in Belgium, France and Luxembourg', in Tax Planning International Review vol. 26, No. 9, 1999 , pp. 8 and 9. 
- Exclusion of foreign workdays: remuneration relating to the days worked outside of Belgium is not taxable in Belgium. Employment income is only taxable to the extent that it relates to activities performed in Belgium.

- The individual is considered as a deemed non-resident for Belgian income tax purposes: personal income of non-Belgian source is not taxable and should not be reported on the Belgian income tax return.

- Expatriate allowances or expense reimbursements are partially free ${ }^{45}$ : expatriate allowances or expense reimbursements received by the employee to cover the costs incurred as a result of employment or secondment in Belgium will not be considered as taxable income.

- Expatriate allowances or expense reimbursements are not subject to Belgian employer and employee security contributions (if conditions are fulfilled).

An application for the expatriate tax regime should be filed with the competent Belgian authorities within six months starting from the first day of the month following the month of the start of the employment or secondment in Belgium.

\subsection{Dutch Expatriate Taxation: 30\% Ruling}

For a long time the Netherlands have had a special deduction for foreign employees of $35 \%$ of the gross income. Initially, the $35 \%$ ruling provided a preferential tax treatment for expatriates, ${ }^{46}$ to cover the extra costs of temporary employment in the Netherlands. Later, the ruling was changed several times ${ }^{47}$ and due to these changes has become more widely applicable.

More recently, the Decree of 20 December 2000 introduced a new tax regime 48 for expatriates by amending the Uitvoeringsbesluit loonbelasting of 1965. The new 30\% ruling was again modified in 2011, in order to increase the period of prohibition of previous residence in Dutch territory from fifteen to twenty-five years.

Regarding the scope of application, Article 8.2.b) sets out that the regime is only applicable to transferred workers with a specific expertise that is scarce or absent in the Dutch labour market. As worded in Article 9.a), for the evaluation of this requisite, account shall be taken of the interrelationship of factors such as: the employee's level of education or his/her experience relevant to the position. Moreover, an employee in middle management or higher of an international concern with at least two and a half years' experience in that concern, shall be considered to have specific expertise in this context ${ }^{49}$ (Article 9.a.1).

The $30 \%$ ruling will start on the first day of employment for registered employees and, according to Article 9.b.1, will be applicable for a maximum period of ten years.

The Dutch regime is essentially based on the concept of extraterritorial expenses, that is to say, the additional costs to be met by the expatriates derived from transfer to another State. In this respect, Article 9.1 provides that the remuneration to extraterritorial employees of the costs involved in living outside the country of origin is considered as a free remuneration for extraterritorial expenses to an amount equal to the sum of $30 \%$ of the basis and the amount of tuition fees. The basis is the sum of the wages and the remuneration for extraterritorial expenses. Wages are here understood as the regular pay for extraterritorial work during the period of extraterritorial employment. Payments that are not directly related, such as pension benefits and golden handshakes, are not therefore considered as wages in this context. The condition is that the employee and employer submit a request jointly to the tax inspector for application of the regime, according to the rules envisaged in Article 9.h.

Basically, the application must include separately the ordinary wages $(70 \%)$ and the remuneration for extraterritorial expenses (30\%). These are taken into account according to their market value and must be agreed separately from the wage, as stated above. For instance, removal expenses belong to extraterritorial costs, and consequently, do not fall outside the $30 \%$ scheme.

Finally, it should be noted that the decision issued by the tax inspector has a retroactive effect from the start of employment as an extraterritorial employee by the employer, providing the request is made within four months after the start of this employment. If the request is made later, the decision would apply starting the first day

\section{Notes}

45 For a detailed exposition, see: Bertin, O.: 'Special tax regime of expatriates in Belgium', published on 9 Dec. 2004, in Droit Fiscalité belge, site d'informations fiscales, juridiques et comptables en droit belge: http://www.droit-fiscalite-belge.com/article874.html (accessed 18 Dec. 2014).

46 The measure was originally aimed at assisting multinationals which send staff on temporary assignment around the world. Later, the measure was restructured: a tax-free reimbursement of $35 \%$ of the salary was given to qualifying individuals, and the option was also introduced to be taxed either as a non-resident or a resident. Evidently, one of the factors to keep in mind in this respect is that the status of non-resident does not give the individual access to the Netherlands tax treaty network, whereas the status of resident taxpayer does. Betten, R.: 'Income tax aspects of emigration and immigration of individuals', IBFD Publications, Amsterdam, 1998 , p. 392.

47 On 4 Jun. 1992, the ruling was revised substantially to be effective as of 1 Sep. 1992. Due to fierce opposition, especially from tax lawyers, the ruling was again modified in August 1992 and in February 1993. With regard to the 35\% ruling, see: Leeflang, K.W.H.: 'Expatriate taxation in the Netherlands: The 35 per cent-ruling revisited', in Intertax vol. 21, No. 12, 1993, pp. 609-612.

48 An English version of the reform can be consulted at http://download.belastingdienst.nl/belastingdienst/docs/sb640uk.pdf (accessed 3 Dec. 2014).

49 As the difficulties involved in demonstrating the fulfilment of these requirements vary from one employee to another, Van Ruiten considers this latter rule of proof concerning the two and a half years of previous experience to be appropriate. Van Ruiten, H.: 'Employment in the Netherlands: conditions of employment, tax and social security aspects', Loyens \& Loeff series, 2008, p. 45. 
of the month following the month in which the request was made.

In our view, the preceding summary shows that the Dutch regime is one of the most accurate systems for expatriate taxation, and even though its implementation has become more complex after the latest reforms, it could be regarded as a model ${ }^{50}$ in order to improve the current Spanish regime.

\subsection{Tax Incentives for Expatriates in France}

The Economic Modernisation Act 776/2008, of 4 August 2008 , introduced important changes ${ }^{51}$ to the specific French tax regime applicable to expatriates established in the French General Tax Code (Code général des impôts). This was yet another amendment to a system established in $2004^{52}$ and frequently modified since then. On 30 July 2009, the French authorities published Decree 389/2009, of 7 April 2009, intended to complete the regime through the new Article 155.B of the French General Tax Code. ${ }^{53}$ The aim of these provisions is to render France more attractive to foreign talent.

Consequently, two different regimes for expatriates are currently in force in the French system: the first one covers foreign employees who are on secondment to France as part of a mobility programme in an international group of companies (Article 81.B, French General Tax Code) ${ }^{54}$; whereas the second one makes it possible for foreign employees directly recruited abroad by a French company (Article 155.B, French General Tax Code) to lawfully benefit from an exemption from personal income tax on part of their remuneration granted in consideration of their presence in France for a limited period.

The point of departure for the French system is the worldwide taxation of an expatriate resident in France. This key element differs from the Spanish system and is closer to other regimes such as the Portuguese or Dutch ones, which follow the same philosophy: the concession of certain tax exemptions provided that the expatriate takes up tax residence and has not been a tax resident during the five ${ }^{55}$ calendar year period preceding the start of the assignment or recruitment.

The tax benefits of the French regime can be summarized as follows:

- Tax exemption for the expatriation bonus: ${ }^{56}$ depending on the situation, that part of the remuneration which is exempt from personal income tax is either the actual amount of the expatriation bonus (prime d'impatriation), as mentioned in the employment contract or officer's appointment, or $30 \%$ of the taxpayer's remuneration (for executives and managers recruited directly abroad by a company based in France).

- Tax exemption for the portion of the expatriate's remuneration which corresponds to work that the employee performs outside France on his/her employer's behalf while the employee concerned is working in France. ${ }^{57}$

- Exemption from personal income tax on up to $50 \%$ of the passive income received by the expatriate from abroad (capital gains on the disposal of shares, bonds and other securities, dividends, interests, intellectual property right royalty fees)..$^{58}$

- Exemption from French wealth tax on his/her assets held outside France for the first five years, whatever the reason for his/her arrival in France, provided he/she has lived outside France for over five calendar years.

Nevertheless, it must be said that the second and third tax incentives described above, which consist of a tax exemption on part of the expatriate's remuneration, are capped, ${ }^{59}$ and the taxpayer has a choice of either: $50 \%$ of

\section{Notes}

50 Also, in this respect: Álvarez Barbeito, P. and Calderón Carrero, J.M.: 'Reflexiones (....)'. Supra pp. 47 and 48

51 See, in this respect: Bidaud, H.: 'Government clarifies tax breaks under impatriate regime', in Tax Notes International vol. 49, No. 11, 2008, pp. 927 et seq.; Michaud, P.: 'Régime des personnes impatriées', Études Fiscales Internationales No. 1, 2008. Available at: http://www.etudes-fiscales-internationales.com/media/02/01/ 1c11a6f0580cde9786709249de5938fc.pdf (accessed 7 Dec. 2014).

52 Lamulle, T.: 'Droit Fiscal', Gualino Editeur, 2007, p. 65; Mémento pratique Fiscal, Edit. Francis Lefêbvre, 2006, pp. 106-107.

53 Previously, expatriate concessions were established in Art. 81.B of the French General Tax Code and, as of 1 Jan. 2008, in Art. 81.C of the same legal Code. Both the original versions and the consolidated texts can be found at the French Government website: http://www.legifrance.gouv.fr/home.jsp.

54 See points 14 and seq. of the Fiscal Instruction 5 F-12-05, of 21 Mar. 2005, which clarify these aspects: http://www11.minefi.gouv.fr/boi/boi2005/5fppub/textes/5f1205/ 5f1205.htm (accessed 7 Dec. 2014)

55 The previous French regime envisaged a period of ten years, which was modified by virtue of Act 1720/2005, of 30 December. See, in this respect, Fiscal Instruction 5 F-1707, which details the changes introduced by said Act: http://84.96.29.178/pdf/407/5f1707.pdf (accessed 7 Dec. 2014).

56 The amount of the tax-free premium is either set out in the employee's employment contract, based on details pertaining to the employee's arrival in France, or determined on a lump-sum basis. In the latter case, the amount of the tax-free premium is equal to $30 \%$ of the remuneration received by the employee. However, anti-abuse measures have been adopted to prevent the taxable salary of the employee being set too low as compared to market and salary levels in the sector in which the employee is working.

57 This exemption concerns the portion paid specifically for duties performed outside of France but for the benefit of the French host company.

58 Under the expatriate regime, passive investment income (such as interest and dividends), capital gains from the sale of securities, copyrights and royalties received from a country with which France has entered into a double tax agreement including a mutual assistance clause, are only liable to income tax on half of the amount.

59 There is a global exemption limit: application of the regime must not lead to the exemption of more than $50 \%$ of the expatriate's total remuneration. However, if this option proves to be more favourable, the employee may opt to have the total expatriation premium fully exempt from tax, but with a limit on the salary paid for duties performed abroad of $20 \%$ of the net taxable salary. 
the taxpayer's total remuneration, or $20 \%$ of the taxpayer's taxable remuneration paid in respect of work performed in France (excluding expatriation bonuses).

This favourable regime expires on 31 December of the fifth year following the year in which the employee started his/her activity in France.

As noted above, for the application of this privileged regime we should start from the premise of the taxpayer's residence in France. Otherwise, the individual will be considered non-resident and will not be able to benefit from the tax incentives established for the 'impatriés', without detriment to other beneficial rules ${ }^{60}$ set out for non-residents.

\subsection{Swedish Expatriate Relief and Flat Rate Taxation in Denmark and Finland}

Under the Swedish system, taxation of expatriates moving to Sweden is based on the length of their stay. A Swedish tax resident is liable to pay tax in Sweden based on worldwide income at ordinary income tax rates. A nonresident individual is subject to tax in Sweden on source income only.

Provided certain conditions are met, foreign key employees (inward expatriates) working in Sweden for limited periods may qualify for a reduction in the income tax liability on their earnings. ${ }^{61}$ The reduction amounts to $25 \%$ and is only applicable if the employer/employee has applied for a ruling within three months after the work started in Sweden. Otherwise, the normal Swedish progressive taxation of personal income applies. The $75 \%$ tax scheme can only apply for three years and only if the stay there does not exceed five years. An individual who has been resident in Sweden during any of the five years prior to the start of the assignment in Sweden cannot qualify for tax relief status. ${ }^{62}$ The individual may not be a Swedish citizen.

This tax relief exempts the following remuneration from Swedish tax and social security contributions: $25 \%$ of salaries and benefits, removal costs (to and from Sweden), home travel expenses (two return tickets per year to the home country for the individual and family members) and tuition fees.

As of 1 January 2012, it is possible to be granted expert tax relief based on the monthly salary, including benefits which the foreign employee receives. If the hired foreign expert receives a salary exceeding two basic amounts per month (approximately SEK 89,000 for the income year 2013), the employee will be granted tax relief.

As we can see, the Swedish system is quite similar to the Dutch one. In contrast to the Spanish regime, it should be noted that the solutions adopted by these countries are less complex from a technical point of view and more coherent with the tax residence concept and with the application of double tax treaties. ${ }^{63}$

Similar solutions have been implemented in Denmark and Finland. With the purpose of strengthening Denmark's international competitiveness by facilitating research and product development, the Danish Parliament passed a bill on 19 June 1992 by virtue of which foreign expatriates on temporary assignment to Denmark were taxed at a flat rate of 30\%. On 14 April 1994, the Danish Parliament approved a second bill whereby the expatriate tax rate was further reduced from 30 to $25 \%$. Following approval by the EU Commission in July 1994, the reduced $25 \%$ expatriate tax rate ${ }^{64}$ came into effect from 1 August 1994.

This earliest version of the regime was followed by a more accurate one, which entered into force on 13 May $2000,{ }^{65}$ and applies to persons taking up a qualifying position on or after that date, or who are or have been

\section{Notes}

60 On 6 Jun. 2014, the Tax Administration issued guidelines regarding the capital gains exemption on the sale of dwellings in France by non-residents provided for in Art. 150 U. II.2nd of the General Tax Code, as modified by the Finance Bill of 2014. The General Tax Code provides for a 'once in a lifetime' capital gains tax exemption for dwellings located in France in favour of EU nationals or nationals of an EEA state with which France has signed a treaty containing an administrative assistance clause. The exemption is subject to the conditions that the seller: a) had been, at any time prior to the sale, a resident of France for at least two consecutive years; and, b) owned the dwelling from 1 January of the year prior to the sale or the sale occurred no later than 31 December of the fifth year following the transfer of the tax residence outside France.

Net capitals gains up to a limit of EUR 150,000 are tax-exempt. The modified provision applies from 1 Jan. 2014. The guidelines delve into these conditions as well as related administrative issues. See: IBFD Tax News Service - 10 Jun. 2014, p. 6.

61 Provisions on tax relief for foreign employees are found in Ch. 11, ss 22-23a of the Income Tax Act. Since 2001, they have covered experts/specialists, researchers and other key personnel, and from 2012, everyone receiving monthly remuneration over a certain level. The legislation provides an additional advantage to companies who need foreign expertise for their Swedish operations. For more details, see: http://skatterattsnamnden.se/forskarskattenamnden/summaryinenglish/ taxreliefforforeignkeypersonnel.4.383cc9f31134f01c98a800018147.html (accessed 7 Jan. 2015)

62 Lindecrona, G.: 'New Swedish tax rules for foreign experts', Liber Amicorum Swen-Olof Loding, Kluwer Law International, 2001, pp. 143 and 144

63 Álvarez Barbeito, P. and Calderón Carrero, J.M.: 'Reflexiones (...)'. Supra p. 48.

64 Campos, G.: 'Expatriate taxation in Denmark: revised 25\% tax rate', in Intertax vol. 23, No. 2, 1995, pp. 86-88.

65 On 3 May 2000, the European Commission decided that Denmark's regime granting a flat rate income tax rate significantly lower than the ordinary Danish tax rate to high-earning employees and researchers recruited from abroad (inward expatriates) did not constitute state aid to companies under Art. 88 (ex Art. 93 ) of the EC Treaty. Commission decision SG (2000) D/103729.

The 1992 regime was notified to the European Commission according to the state aid provisions of the EC Treaty (Art. 88.3, ex Art. 93.3). The Commission considered the regime to constitute state aid, but nevertheless approved it.

In parallel with its decisions on Denmark's expatriate regime, the European Commission also issued a decision on Sweden's expatriate regime (Commission press release IP/00/429). Ottosen, A. M.: 'Denmark's favourable tax regime for inward expatriates', in Bulletin for International Taxation vol. 54, No.12, 2000, pp. 646 and 647. 
subject to the previous pilot scheme. The major features and requirements of the regime are set forth in Law No. 913 of 16 December 1998, Statutory Order No. 319 of 8 May 2000, and Circular No. 130 of 28 June 2000.

Employees who satisfy the conditions set out below and become tax residents in Denmark are eligible for the regime. The employee must take up the position immediately after the date that he/she becomes fully subject to tax in Denmark. An individual becomes resident in Denmark for tax purposes when he/she establishes a permanent home in Denmark or is present in Denmark for at least six consecutive months.

In addition, to qualify for the regime, the employee must not have been, during the preceding three years, either a Danish tax resident or a non-resident subject to Danish taxation on income from employment or a permanent establishment in Denmark. Furthermore, prior to becoming an employee of the Danish company, the employee must not have been seconded to work abroad by that company or a company belonging to the same group.

There are no specific requirements with regard to the substance or content of the employee's job. In practice, it has been accepted, for example, that foreign football coaches and athletes can benefit from the regime. However, the work must be performed in Denmark. In this respect, according to Circular No. 130 of 28 June 2000, no more than one-third of the work can be performed abroad.

By referring to inward expatriates who are not researchers, ${ }^{66}$ this system is only available to high-earning employees whose monthly salary, after deductions for the Danish labour market supplementary pension contribution, social security contributions and special pension contribution, exceeds a stipulated amount.

The tax base cannot be reduced by any kind of allowance ${ }^{67}$ related to the expatriate regime. Tax at the rate of $25 \%$ is levied on the tax base, whilst the ordinary Danish marginal tax rate for personal income is $63.3 \%$, including the aforementioned social/pension contributions.

An employee may benefit from the favourable tax regime for a maximum period of thirty-six months. There is no minimum period. Within this time frame, the employee may hold one or more different positions with one or more employers. The aggregate of thirty-six months must be within a ten-year period, which starts with the commencement of the first employment contract.

Similarly to the Danish regime, under the Finnish system for expatriate taxation, gross employment income is taxed at a flat rate of $35 \%$. It should be emphasized that the effects derived from these flat rate taxation models are very similar to those of the Dutch and Swedish models.

\subsection{Expatriate Regimes in Other Jurisdictions}

Evidently, besides the models described above, there are numerous other expatriate regimes in other jurisdictions. In Australia, for instance, some residents holding temporary visas are only subject to tax on the source income. Similarly, in Chile ${ }^{68}$ and Romania, those taxpayers who are not nationals are taxed under the source State principle for three years after becoming residents; the same advantageous rule is applied by Colombia for the first five years after they acquire residence in its territory.

In reviewing some other models, it should be noted that in Japan, ${ }^{69}$ non-permanent residents are only taxed on income obtained in Japan and on foreign source income either paid or remitted to Japan. A resident is an individual whose domicile is in Japan or who has resided in Japan continuously for a year or more. Residents are further classified into permanent residents or nonpermanent residents. The Japanese system attributes the consideration of non-permanent resident to those taxpayers who are not nationals but have entered Japan with an employment contract of one year or longer, or who have lived in Japan (have their dwelling - jusho - or temporary place of abode - kyosho -) for less than five of the past ten years and have not formed an intention to reside in Japan permanently. This definition of nonpermanent resident is effective from 1 April 2006. Those taxpayers who have resided for more than five of the past ten years in Japanese territory, or who have formed an intention to remain in Japan permanently, are considered permanent residents for tax purposes and are taxed on their worldwide income.

Furthermore, it should be noted that other countries, such as Austria, ${ }^{70}$ Cyprus, Italy, Malta, Switzerland and Turkey have also established preferential tax treatment for expatriates.

\section{Notes}

66 Researchers are granted an especially favourable position under the expatriate regime. See, in this respect: Ottosen, A. M.: 'Denmark's favourable (...)'. Supra p. 646.

67 Travelling expenses, removal costs, double rent, trade union contributions, unemployment insurance fund contributions, pension scheme contributions and personal allowances cannot be deducted from the tax base. Mandatory payments to foreign social security schemes and certain other payments, however, are deductible. Ottosen, A. M.: 'Denmark's favourable (...)'. Supra p. 645.

68 The Chilean regime for expatriates is quite similar to the Spanish one. See: Laurie, M.: 'Chile: Ordinance changes reporting rules for foreign residents', in Tax Notes International vol. 37, No. 13, 2005, p. 1.149

69 See: PricewaterhouseCoopers LLP: 'International Assignment Services - Taxation of International Assignees - Country: Japan', available at http://www.pwc.com/us/en/hrinternational-assignment-services/assets/japan-folio.pdf (accessed 23 Dec. 2014).

70 See: Income Tax Guidelines, paras 1038a-1038i; originally published in the Official J. of the Austrian Tax Administration 1998/36; Züger, M., Lechner, E. and Treer, H.: 'Tax consequences for expatriates coming to Austria to work', in Bulletin for International Fiscal Documentation vol. 58, No. 12, pp. 570 and 571 


\section{The recent Spanish tax Reform: a new REGIME FOR EXPATRIATES}

\section{I The Report of the Spanish Commission of Experts and the Income Tax Act (Law 26/20 (4):A Critical Overview}

Although the expatriate tax rules in Spain are very favourable, the Spanish Government has been exploring ways to make these rules even more flexible in order to widen their application and, therefore, attract not only more foreign experts, but also property investors and pensioners to Spain.

In February 2014, the Spanish Commission of Experts for the Tax Reform delivered its Report, ${ }^{71}$ which tended to broaden the scope of application of the current system, taking into account the measures introduced in other European and non-European countries.

Bearing the international context in mind, the Commission of Experts suggested several additional measures that would render the present regime more competitive and consequently increase tax collection in Spain. The main reforms proposed are as follows:

- One possibility being considered is to extend the benefit of the $24 \%$ tax rate not only to those foreigners transferred to Spanish territory because of an employment contract, but also to those individuals who carry out economic activities without a permanent establishment, managers, significant shareholders, pensioners or recipients of capital or property income. This proposal was influenced by the British and the Portuguese regimes, under which there is no discrimination between the potential beneficiaries depending on the nature of the income.

- Another possibility is to eliminate the EUR 600,000 limit on the income obtained in each of the fiscal years concerned.

- Another suggestion has been the elimination of the clause stipulating that when part of the work is performed abroad, the resultant foreign income should not exceed $15 \%$ of the total salary received for work performed in each calendar year. An alternative proposal is to establish a percentage of $50 \%$ of the employment income.

- Two proposals have been made with regard to time requirements: the beneficiaries must not have been residents in Spain in the five (instead of ten) years prior to their transfer to Spanish territory, and the option for being taxed at a $24 \%$ tax rate will apply during the fiscal year in which the change of residence takes place and the ten (instead of five) subsequent fiscal years, provided that certain conditions are complied with.

These changes have been spurred by evidence that expatriates are taxed not only under the Spanish Income Tax regime, but also under the Wealth Tax and the Inheritance Tax regimes. In the case where non-residents come to Spain and become residents because of the length of their stay in Spanish territory, they are considered taxpayers under the Income Tax regime (with the option) and they are levied on their unlimited tax liability (in the case that they exercise the option) under the Wealth and Inheritance Tax regimes. This tax burden, higher in comparison to other Member States (most of which have abolished the Wealth Tax), could dissuade potential expatriates from moving to Spain. Similarly, it has also been suggested that imputation of immovable property income to individuals should be eliminated, since it could discourage potential investors from locating their residence in Spain.

The Spanish system is less advantageous in comparison with other competitor countries, which have established a special regime for non-habitual residents. This is even more obvious in the case of pensioners. As is well known, most foreign pensioners resident in Spain come from States with a tax treaty based on the OECD MC. Under this model, public pensions shall be taxable only by the State making the payment (State of the fund), whereas the State of residence of the recipient is given exclusive taxation of pensions paid in consideration of past private employment, even in cases where the employment concerned was exercised in the other Contracting State. In the latter case, the pensioner will be taxed at high tax rates of up to $56 \%$ in the case of residence in Spain, and $40 \%$ in the hypothesis of residence in a State without a double tax treaty. Needless to say, this onerous regime can deter nonresidents from acquiring residence in Spain and from contracting pension funds in Spain.

In our view, however, this should be considered in the light of the principle of equity. In contrast to the beneficial measures created to attract talent, which can be justified as a means to ensure attainment of the objective pursued, namely to foster the development of research, knowledge and innovation in Spain, it should be noted that in the case of pensioners or recipients of movable or immovable property income, there is no extra-fiscal purpose - apart from that of tax recovery - which could justify the difference in treatment granted to these taxpayers. Our criticism is thus focused on the lack of justification for these favourable measures, because they engender two categories of pensioners or of recipients of movable or immovable property income: those resident in Spain, who will be taxed according to the tax rates

\section{Notes}

Report of the Spanish Commission of Experts, February 2014, available at http://www.abc.es/gestordocumental/uploads/economia/fe007a24af859ec8ce790387 ba6b7755.pdf. 
described, and those expatriates (or even Spanish nationals who moved abroad and then came back to Spain after five years) who, for a period of ten years, will only be taxed at $24 \%$. From our point of view, in the absence of a valid justification, this divergent tax treatment contravenes Spanish constitutional principles and is unacceptable.

However, the Draft of 23 June 2014 on Income Tax partially ignored the proposals made by the Commission of Tax Experts - especially as regards the extension of the option to pensioners and recipients of movable and immovable property - and only introduced two major amendments to the current system: firstly, the exclusion of professional sportspeople as potential beneficiaries of the option, and, secondly, an increase in the flat tax rate of $24 \%-45 \%$ when the total income obtained (except from dividends, interest and capital gains) exceeds EUR $600,000.01$. It also incorporated a tariff with a fixed quota and tax rates of 19, 21 and $23 \%$, for dividends, interests and capital gains derived from the transfer of assets, depending respectively on the corresponding taxable base.

Both the new Bill on the Income Tax Act ${ }^{72}$ and the final version approved by Act 26/2014, of 27 November $2014,{ }^{73}$ maintain the same wording of Article 93 envisaged in the Draft. The new regime on expatriates, established on the occasion of a global reform of the Income Tax Act, is applicable from 1 January 2015, according to Temporary Regulation No.17 of the aforementioned Act.

In our opinion, the changes introduced changes deserve a different appraisal. The latter one is welcomed by experts, who have pressed for an application of the regime more in accordance with the ability to pay principle. ${ }^{74}$ However, the exclusion of football players and other professional sportspeople from the scope of application of this system, although desirable, constitutes flagrant discrimination according to the employment performed. Although we agree with the final objective, we consider that the legislator could have used a more appropriate route to exclude those professionals with high earnings who nevertheless do not perform highly qualified activities and consequently do not contribute to the growth of knowledge and innovation in Spain. As we have emphasized in the preceding lines, in order to be justified under constitutional principles, the Spanish regime should only be addressed to those highly qualified professionals and experts, as envisaged in the Dutch, Portuguese and Belgian models, with skills which are scarce in Spain.

\subsection{Alternative Solutions for a New Spanish Expatriate Taxation System}

As has been demonstrated, the Spanish taxation system for expatriates currently in force still gives rise to many interpretation issues, together with problems of technical application and possible breaches both of the Spanish Constitution and of European law. ${ }^{75}$ Consequently, it is evident that the system should be amended again in the near future in order to improve all these controversial aspects.

As noted above, we consider that the special regime should apply to transferred workers in strategic sectors who carry out specific activities in a highly qualified field. ${ }^{76}$ Only this extra-fiscal purpose could, in our view, justify the significant tax advantages granted to expatriates without violation of constitutional principles, provided that other conditions are met in terms of proportionality with the objective pursued.

Furthermore, we consider that the point of departure should be taxation of the expatriate, as a resident in Spain, on his/her worldwide income, ${ }^{77}$ in line with other national regimes such as the Dutch, French and Portuguese ones. At present, the Spanish legislator has created a special category of residents, similar to the British system, under which expatriates are levied exclusively on their source income, notwithstanding their consideration as residents in Spain. In fact, it is designed as a kind of hybrid status of taxation $^{78}$ or, in other words, a 'cross-border situation between residence and non-residence' which establishes a new taxable event, ${ }^{79}$ exclusively referring to income obtained from Spanish territory by a resident. ${ }^{80}$ However, this is evidently only one aspect of the taxable event of Spanish Income Tax.

\section{Notes}

Published in the Official Gazette of the Spanish Parliament on 6 Aug. 2014.

Published in the Official Spanish Gazette of 28 Nov. 2014.

Chico de la Cámara, P.: 'Algunas propuestas (...)'. Supra p. 102.

Sanz Clavijo, A.: 'El régimen tributario especial en el IRPF de los trabajadores desplazados a España', in Documentos de trabajo No. 2/2013, Instituto de Estudios Fiscales, pp. 51 and 52.

Also in this respect: Chico de la Cámara, P.: 'Algunas propuestas (...)'. Supra p. 102; Sanz Clavijo, A.: 'Propuestas (...)'. Supra p. 209.

López Lubián, J.I.: 'El régimen (...)'. Supra p. 63

Carmona Fernández, N.: 'Guía (...)’. Supra pp. 89 and 90; Álvarez Barbeito, P. and Calderón Carrero, J.M.: 'Reflexiones (...)’. Supra p. 22.

Litago Lledó, R.: 'El IRPF de los trabajadores extranjeros temporalmente residentes en España', in Tribuna Fiscal No. 184, 2006 , p. 21.

Falcón y Tella suggests the establishment of two regimes: the first addressed to qualified foreign investors exclusively focused on their source (Spanish) income or income remitted from abroad; and the other addressed to directors, executives of multinational enterprises and highly qualified workers, which should be modified in line with the proposals of the Commission of Experts, or designed according to the first one noted above. Falcón y Tella, R.: 'El cierre registral, los residentes no domiciliados y otras curiosidades del Informe de los expertos sobre la reforma fiscal', en Quincena Fiscal No. 11, 2014, pp. 14 and 15. 
Therefore, the future fiscal reform should involve taxation of expatriates on the basis of their unlimited tax liability. This measure would not only solve double taxation problems, but also undesirable situations of double non-taxation which more often than not occur as a consequence of the joint application of certificates of residence ${ }^{81}$ and double tax treaties.

However, there are various alternatives among the possible solutions aimed at rendering the regime attractive. Taking as a premise that the individual will be taxed on his/her global income, irrespective of its nature or source, one possibility could be to consider specific expenses derived from the condition of being an expatriate (such as removal costs, or rent on a dwelling in Spain, for instance) as deductible expenses from the labour income, or to declare an exemption of a significant amount of his/her labour income. ${ }^{82}$ Alternatively, another suggestion has been to exonerate any extraordinary income paid to the foreign expert - as labour income - as compensation for his/her condition of expatriate. ${ }^{83}$ These proposals focus on the tax base in order to render our tax system more competitive, by adapting it to the special context of these individuals who are in demand in the Spanish labour market.
Another possibility could be to introduce a deduction on the tax quota, ${ }^{84}$ instead of the present application of a flat tax rate on Spanish sourced income. This configuration of the system would unquestionably be more in line with the ability to pay principle, with a minimum restriction of the equality principle.

Going back to professional sportspeople, the ideal solution in our view would be to consider their earnings as an irregular income, ${ }^{85}$ bearing in mind that the income received is high, but only for a short number of years.

The new Act introduces some positive changes, together with some unsatisfactory ones. Compared to the previous system, the new regime is less controversial but still envisages many aspects that should be improved, as we have indicated in the preceding lines. This regulation and the foreseeable amendments will be of great importance to most expatriates; thus the legislator should bear in mind that it should be far more consistent and practical, but without losing sight of the idea that considerations related to economic competitiveness must never prevail ${ }^{86}$ over the principles enshrined in both the Spanish Constitution and European law.

\section{Notes}

81 In this regard, López Lubián suggested the creation of a new model of the Spanish certificate of residence, specifically designed for expatriates, declaring the double special circumstance of residence in Spain but with exclusive taxation on their Spanish sourced income. López Lubián, J.I.: 'El régimen (...)'. Supra p. 64.

82 López Lubián, J.I.: 'El régimen (...)'. Supra p. 63.

83 Sanz Clavijo, A.: 'Propuestas (...)'. Supra p. 211. In this author's opinion, it would be desirable to distinguish between the different aims of the tax regime (either to attract highly qualified workers or simply to incentivize the entrance of workers - whether qualified or not - together with foreign investment) in order to define the content of the regime.

84 García Carretero, B.: 'La fiscalidad (...)'. Supra p. 157.

85 Gorospe Oviedo, J. I.: 'Los regímenes (...)'. Supra p. 39.

86 This topic brought about an interesting discussion in Sweden and the Netherlands. Lindecrona, G.: 'New Swedish (...)'. Supra p. 142; Kinnegin, J.W.: 'Dutch withholding tax exemption extends to specialized foreign employees', in Tax Notes International vol. 33, No. 4, 2004, pp. 371 and seq. 


\section{[A] Aim of the Journal}

This established international tax journal offers detailed coverage of direct tax, indirect tax, and social security from both legal and economic angles, and provides 12 issues a year of practical, up-to-date, high-level international tax information. Coverage includes all aspects of transnational tax issues. The journal includes authoritative, reliable content, written for tax attorneys, practitioners (litigation and transactional) in other areas where international tax issues are a concern, and academics.

\section{[B] Contact Details}

Manuscripts should be submitted to the General Editor, Fred de Hosson.

E-mail address: Fred.deHosson@bakermckenzie.com

\section{[C] Submission Guidelines}

[1] Manuscripts should be submitted electronically, in Word format, via e-mail.

[2] Submitted manuscripts are understood to be final versions. They must not have been published or submitted for publication elsewhere.

[3] Articles in the non-peer reviewed sections should preferably not exceed 10.000 words and articles in the peer-reviewed section should preferably not exceed 14.000 words.

[4] Only articles in English will be considered for publication. Manuscripts should be written in standard English, while using 'ize' and 'ization' instead of 'ise' and 'isation'. Preferred reference source is the Oxford English Dictionary. However, in case of quotations the original spelling should be maintained. In case the complete article is written by an American author, US spelling may also be used.

[5] The article should contain an abstract, a short summary of about 200 words. This abstract will also be added to the free search zone of the Kluwer Online database.

[6] A brief biographical note, including both the current affiliation as well as the e-mail address of the author(s), should be provided in the first footnote of the manuscript.

[7] An article title should be concise, with a maximum of 70 characters.

[8] Special attention should be paid to quotations, footnotes, and references. All citations and quotations must be verified before submission of the manuscript. The accuracy of the contribution is the responsibility of the author. The journal has adopted the Association of Legal Writing Directors (ALWD) legal citation style to ensure uniformity. Citations should not appear in the text but in the footnotes. Footnotes should be numbered consecutively, using the footnote function in Word so that if any footnotes are added or deleted the others are automatically renumbered.

[9] Tables should be self-explanatory and their content should not be repeated in the text. Do not tabulate unnecessarily. Tables should be numbered and should include concise titles.

[10] Heading levels should be clearly indicated.

For further information on style, see the House Style Guide on the website: www.kluwerlaw.com/ContactUs/

\section{[D] Peer Review}

[1] At specific request by the author, an article can be submitted for peer review.

[2] In this procedure, articles are evaluated on their academic merit by two (anonymous) highly esteemed tax law experts from the academic world. Only articles of outstanding academic quality will be published in the peer-reviewed section.

\section{[E] Regular Review Process}

[1] Before submission to the publisher, manuscripts will be reviewed by the General Editor and Editorial Board and may be returned to the author for revision.

[2] The editors reserve the right to make alterations as to style, punctuation, grammar etc.

[3] The author will receive PDF proofs of the article, and any corrections should be returned within the scheduled dates.

\section{[F] Copyright}

[1] Publication in the journal is subject to authors signing a 'Consent to Publish and Transfer of Copyright' form.

[2] The following rights remain reserved to the author: the right to make copies and distribute copies (including via e-mail) of the contribution for own personal use, including for own classroom teaching use and to research colleagues, for personal use by such colleagues, and the right to present the contribution at meetings or conferences and to distribute copies of the contribution to the delegates attending the meeting; the right to post the contribution on the author's personal or institutional web site or server, provided acknowledgement is given to the original source of publication; for the author's employer, if the contribution is a 'work for hire', made within the scope of the author's employment, the right to use all or part of the contribution for other intra-company use (e.g. training), including by posting the contribution on secure, internal corporate intranets; and the right to use the contribution for his/her further career by including the contribution in other publications such as a dissertation and/or a collection of articles provided acknowledgement is given to the original source of publication.

[3] The author shall receive for the rights granted a fee of EUR 31,66 per page (in final layout), a free copy of the issue of the journal in which the article is published, plus a PDF file of his/her article. 